\title{
A Competing Risks Analysis of Strike Duration in Spain: Agreement and Non-Agreement Outcomes
}

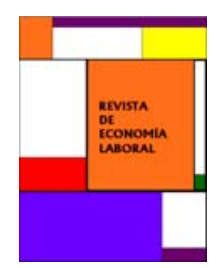

\author{
Silviano Esteve Pérez*, Mariluz Marco Aledo ${ }^{\dagger}$, \\ María Engracia Rochina Barrachina* 1 \\ * Universidad de Valencia, Spain, and LINEEX \\ $\dagger$ Universidad de Valencia, Spain
}

Received 20 September 2005; accepted 7 March 2006

\begin{abstract}
This paper analyses the determinants of strike duration in Spain taking into account different outcomes (agreement and non-agreement). We find that duration decreases with the number of strikers or several applicable agreements to strike units. It rises with minimum services, the degree of strike support and in private firms. With respect to the real GDP growth rate, duration is pro-cyclical in strikes ending in agreement and countercyclical in those ending without agreement. Uncompensated and unexpected inflation decreases duration for agreement strikes and increases it for non-agreement ones. The 1997 labour reform, with a wide social consensus, raises the chances of the agreement outcome.
\end{abstract}

Keywords: Strike duration; strike outcome; competing risks hazard models JEL Classification: J52, C41

\section{Introduction.}

Studies about strike activity in Spain are fairly scarce, both from a theoretical and an empirical point of view. To the best of our knowledge, from a theoretical standpoint there is only a comprehensive revision of the theoretical literature on strike incidence and duration in Jiménez-Martín and Marco (1998). From an empirical point of view, there are only two studies that analyse the determinants of strike incidence in collective

\footnotetext{
1 Author for correspondence: erochina@uv.es. We wish to thank comments from the editor, an anonymous referee and Sergi Jiménez-Martín. Financial support from IVIE, Fundación Banco Herrero and CICYT (SEJ2005-05966, SEJ2005-08783-C04-01) is gratefully acknowledged.
}

(C) Revista de Economía Laboral 
bargaining strikes in large Spanish firms (Jiménez-Martín et al., 1996) and the slope of the concession function, that is, the relationship between strike durations and wages (Jiménez-Martín, 1999). Furthermore, none of the previous empirical studies has examined the determinants of strike duration.

The aim of this paper is twofold: on the one hand, to empirically analyse the determinants of strike duration in Spain; and, on the other hand, given that strikes may end either in agreement or non-agreement, to explore the differences in the determinants of the strike outcomes. In some other countries most strikes end with contracts (for instance, in the US and Canada). Indeed, the econometric studies commonly restrict attention to settled strikes. A substantial chance of gains from trade exists between parties. In contrast, in the Spanish case once strikes do occur they do not end almost invariably with an agreement, but in a high proportion in dissolution of the bargaining relationship.

We use registry data for the period 1986-1999, drawn from the Estadística de Huelgas y Cierres Patronales (EHCP, hereafter), ${ }^{2}$ carried out by the Spanish Ministry of Labour and Social Affairs. The dataset includes information on all strikes taking place in Spain and has many desirable features. First, strikes can be followed on a regular basis and under unified criteria since 1986. Hence, it permits to examine the relationship between strike duration and business cycle and the influence of regulatory changes that affect industrial relations. Secondly, the dataset comprises a large number of strikes. Thirdly, it includes a significant number of variables to characterise different aspects of each strike. Fourthly, it is possible to examine strike duration taking into account the different motives to strike (mainly, collective bargaining strikes and strikes arising from other causes). Fifthly, our data includes strikes both in manufacturing and non-manufacturing. Finally, and crucial for the purpose of this paper, the information allows distinguishing between different strike outcomes: agreement and non-agreement. Hence, the data set used in this study, a longitudinal file of 14120 strikes between 1986 and 1999, is sufficiently rich to allow for testing a variety of hypotheses concerning the influence of several factors on strike duration.

The methodology used includes the estimation of duration models, which allows accounting for different strike outcomes. Duration models focus on the occurrence probability of ending a strike at a given point in time, conditional to the non-occurrence of that event up to that point. Thus, they allow controlling for both occurrence and duration of the event. Traditional cross-section techniques, such as OLS, Logit or Probit, have

\footnotetext{
${ }^{2}$ See Marco (1996) for further information about this data source.
} 
some drawbacks compared to duration methods. First, they are constrained to analyse the unconditional average probability of occurrence of the event during the analysed period, treating in a similar manner events ending at the beginning of the period and at the end, when conditions may have changed. Secondly, these methods make use of distributional assumptions that may be inadequate for duration data. Thirdly, duration methods are also adequate in the presence of rightcensored observations. The sampling scheme of the EHCP avoids left censoring problems by including information only for strikes starting in and after 1986. Finally, the duration methods used permit a fully nonparametric treatment of the baseline hazard, which allows examining the effect of (strike) duration on the risk of ending a strike (duration dependence).

To anticipate the results, strike duration is found to decrease with the number of strikers or several applicable agreements to strike units. It increases with minimum services, the degree of strike support and in private firms. The unemployment rate does not affect strike duration, but duration is pro-cyclical with real GDP growth in agreement strikes and counter-cyclical in non-agreement strikes. Uncompensated and unexpected inflation decreases duration for agreement strikes and increases it for non-agreement ones. Finally, the 1997 labour reform seems to have increased the chances for the agreement strike outcome. Our findings suggest that it is crucial to distinguish between different strikes outcomes to capture important differences in the determinants of strike durations.

The rest of the paper is organised as follows. Section 2 briefly reviews the main economic theories on strike activity. Section 3 describes the basic features of the industrial relations in Spain. The dataset and explanatory variables are presented in section 4 . In section 5, the econometric methodology used is briefly outlined, in particular the competing risks hazards model. In section 6 , we discuss the main results, and section 7 concludes.

\section{Main economic theories about strike duration.}

There are two main strands of literature that explain why strikes occur, and subsequently their duration. The first strand originated in Hicks (1932) Theory of Wages. This author concluded that most strikes are mistakes or accidents that occur during negotiations. He also suggested that the union will be more willing to accept a lower wage the longer the strike goes on. Hicks argues that this negative relationship between the 
union's demands and strike duration (the "union resistance" curve) arises from what he calls "temporary privations" or economic difficulties/costs in which workers incur during the strike. On the firm side, there is a "firm concession" curve that determines the wage a firm is willing to offer for each strike duration. Given that the firm will probably face higher costs as duration increases, Hicks justifies a positive slope for the "firm concession" curve. The final duration and the final agreement on wages between the firm and the union will be determined as an equilibrium point of the two curves, and the location of this equilibrium will depend on the strike duration costs of both parties. Kennan (1980) and Reder and Neumann (1980) argue that even if strikes are mistakes, they should occur less often and be shorter the higher the joint costs for the union and the firm.

The second strand of the literature considers strikes as an information revealing device in presence of asymmetric and private information. Ross (1948) stressed the divergent aims of the union leaders and the rank and file union members by recognizing that union leaders are motivated by personal promotion and the growth of the union. Ashenfelter and Johnson (1969) formalised Ross' political model of unions into a theory of strikes where the absence of complete information in the union rank and file is an essential feature of the strike model. However, the union leaders and the firms' management share all relevant information for the negotiation process. The strikes occur when the wage expectations of the rank and file are unrealistically high with respect to the amount the firm is willing to pay. Then, the union leaders use the strike to convince the rank and file that a high wage is not possible. Consequently, an implication of this theory is that the union's wage demands should fall during a strike. The main criticism of the Ashenfelter-Johnson model is the lack of rationality behind the unions' behaviour. In their model, economic rationality lies on the firm side, which after taken as given (known) the negative sloped "union concession" curve maximises the present discounted value of its profits. ${ }^{3}$ This model ignores bargaining interactions between the two parties (it is a one-sided model).

Later developments in this second strand, based on noncooperative bargaining theory, ${ }^{4}$ provide a rationalisation for the downward-sloping resistance schedule of Hicks or the union concession

\footnotetext{
3 They assume the existence of a Hicksian type declining function of wages in relation to strike length. That is, a type of "union resistance" curve now called "union concession" curve.

4 There are a number of surveys of collective bargaining and strikes that provide useful background. See, for example, Hayes (1984), Kennan (1986), Kennan and Wilson (1989, 1990, 1993), Card (1990a), and Cramton and Tracy (2003).
} 
curve of Ashenfelter and Johnson. ${ }^{5}$ Strikes are a means of communicating private information about the firm's willingness to pay. A firm with a low willingness to pay prefers to endure a strike in order to settle at a low wage. Hence, a firm can signal this private information through its willingness to endure and to lengthen a strike. Consequently, as the strike continues, the union is more pessimistic about the firm's profitability. The strike is here an ex-ante efficient bargaining tool rather than a mistake. The firm uses it to show its willingness to pay to the union and the union uses it to discriminate between different firm types (high and low rent ones).

The asymmetric and private information models are a main ingredient in the analysis of strikes and its duration. They predict that strikes should be more frequent and last longer with high-expected profits by the unions that do not correspond to real profits by the firm. Higher unions' uncertainty is expected to be associated with longer strike durations both because of initial wage demands out of line with the amount the firm is willing to pay, and greater union difficulties to attain information on the size of the economic rent grasped by firms. However, there are alternative bargaining models assuming private information such as the war-of-attrition models. In these models, uncertainty is not related to the size of the pie to be split between the firm and the workers, but to the costs in which the two parties incur during the strike. This is a winner-to-all game where the party with lower costs enjoys the highest bargaining power (that is, the biggest resistance time in negotiations) and, then, its demands will ultimately prevail. ${ }^{6}$

Therefore, there are a number of theoretical studies on strike activity. However, given the large range of factors determining it, no theoretical model adequately captures all of them. Despite that, regarding strike duration, there seems to be a certain consensus that it is inversely related to: (i) the costs of all the parties involved in the bargaining process; (ii) information availability. These factors permit to justify most of the variables used in the empirical analysis of strike duration. For instance, economic and labour policies are relevant to strikes as long as they can make more relevant information available, and then reduce uncertainty for the bargaining process, or they can reduce costs inherent to the

\footnotetext{
${ }^{5}$ Jiménez-Martín (1999) using Spanish data, and Cramton et al. (1999) using Canadian data, find an insignificant slope to the concession curve (the relationship between wages and strike durations) when estimated with ordinary least squares, and a significant negative slope when estimated with instrumental variables. For studies estimating the slope for the wage concession curve treating the duration variable as exogenous, see McConnell (1989) and Card (1990b).

${ }^{6}$ See Kennan and Wilson (1989) and Card and Olson (1995).
} 
negotiation process. Hence, they should contribute to shorter strikes. ${ }^{7}$ Also, the traditional empirical concern in the strikes literature about the link between strike duration and the economic cycle (supporting most of the times a counter-cyclical behaviour of strike duration) relies on the idea that the economic cycle proxies for time-varying strike opportunity costs and outside options to both parties. ${ }^{8}$ Furthermore, the relative costs to both parties contribute to their relative bargaining power. Finally, the coverage and coexistence of current contracts also influences the union's behaviour. The intuition behind this is that the union will decide to continue on strike if the extra costs associated with it are lower than the extra gains the union expects to obtain from a longer strike. If the wage in the current contract is sufficiently high, it can cause the union to stop the strike. Thus, for instance, after a period of uncompensated inflation, real wages are lower in the current contract and there is a greater incentive for the union to lengthen the strike.

To conclude, the variables commonly used to build up a model for strike duration depend heavily on the available data and the institutional features of the country. A common limitation of the data on strikes is the inability to control for learning from past negotiations in the same bargaining unit or the lack of information on prior contracts affecting the bargaining unit.

\section{Industrial relations in Spain.}

The industrial relation system in Spain displays some noteworthy features (Table 1). It is remarkable the apparent contradiction between the low affiliation rate (about 7-11 percent in the 1980s and 1990s, reaching $15 \%$ in 2000) and the ability of Spanish unions to mobilize a large number of non-member workers. The Spanish experience suggests that the impact of organization on strike involvement is not merely a question of union density.

\footnotetext{
7 Cramton et al. (1999) found that strikes are very much influenced by labour policy and legislation, given that they may change the associated costs to the strike and bargaining process.

${ }^{8}$ See Kennan (1985), Harrison and Stewart (1989, 1994), Cramton et al. (1999), Vroman (1989), Booth and Cressy (1990), and Ingram et al. (1993).
} 
Table 1: Comparative characteristics of industrial relations

\begin{tabular}{lcccccc}
\hline \multirow{2}{*}{ CHARACTERISTICS } & \multicolumn{2}{c}{ UK } & \multicolumn{2}{c}{ SPAIN } & \multicolumn{2}{c}{ FINLAND } \\
\cline { 2 - 7 } (. Density & Mid 80 & Mid 90 & Mid 80 & Mid 90 & Mid 80 & Mid 90 \\
( $\%$ and rank) & $51 \%$ & $39 \%$ & $7 \%$ & $11 \%$ & $69 \%$ & $72 \%$ \\
2. Coverage of collective & $(12)$ & $(16)$ & $(24)$ & $(29)$ & $(4)$ & $(4)$ \\
bargaining (\% and rank) & $70 \%$ & $40 \%$ & $60 \%$ & $70 \%$ & $90 \%$ & $90 \%$ \\
\hline 3. Bargaining level (rank) & 1 & 1 & $4 / 3,5$ & 3 & 5 & 5 \\
\hline 4 Coordination (rank) & 1 & 1 & $4 / 3,5$ & 3 & 5 & 5
\end{tabular}

Sources: OECD Employment Outlook, 2004 and International Handbook of Trade Unions, 2005.

D and 2: Percentage of employees who are union members or covered by collective bargaining, respectively. Rank refers to rank out of 30 countries. OECD Employment Outlook 2004, Table 3.3.

(3) : Refers to level of collective bargaining, ranging from $1=$ company and plant level predominant, $2=$ Combination of sector and company/plant level, with and important share of employees covered by company bargains, 3 = Sector-level predominant, $4=$ predominantly sector bargaining, but also recurrent central-level agreements, $5=$ Central-level agreements of overriding importance. OECD, Employment Outlook 2004, Table 3.5.

4: Refers to the degree of coordination among employers and among unions. $1=$ Fragmented company/plant bargaining, little or no co-ordination by upper-level associations., $2=$ Fragmented sector and company-level bargaining, with little or no pattern-setting, $3=$ Sector-level bargaining with irregular pattern setting and moderate co-ordination among major bargaining actors, $4=$ Informal coordination of sector and firm level bargaining by (multiple) peak associations; Co-ordinated bargaining by peak confederations, including government-sponsored negotiations (tripartite agreements, social pacts), or government imposition of wage schedules; regular pattern-setting coupled with high union concentration and/or bargaining co-ordinations by large firms; government wage arbitration; $5=$ informal coordination of sector level bargaining by an encompassing union confederation; coordinated bargaining by peak confederations or government imposition of wage schedule/freeze, with peace obligation. OECD Employment Outlook 2004, Table 3.5.

The apparent contradiction between low union affiliation and high strike participation can be explained by a number of factors. First, the workers' representative system in Spain, based on workers' committees, encourages unity of action, despite low union density, particularly in small and medium sized firms. Typically more than 80 percent of workers participating in workers' committees elections vote for union candidates and are sympathisers of the unions, even though most of them are not members. However, this is not enough to support sustained enterprisebased union activity, given the very low membership levels. Secondly, Spanish legislation confers the characteristic of "automatic general effectiveness" to labour agreements. Hence, agreements reached in negotiations are applicable to both union and non-union members. This is a feature of the Spanish system of industrial relations making most workers be effectively covered by collective bargaining (ranging between 60 to $70 \%$ during the 1980 s and 1990 s, and increasing up to $80 \%$ in $2000-$ see Table 1-). Thirdly, the degree of coordination between the two main trade unions in Spain (UGT and CCOO) is relatively high. Inter-union 
conflict in the context of industrial action does exist in Spain but it does not seem to be as significant as in other countries. In Spanish large firms, the force of the two major confederations are often evenly balanced, which makes them cautious before launching unilateral calls for action, despite inherent temptation in anticipation of improved electoral results if they succeed. In smaller firms, the union position is usually so weak that preserving unity via a workers' committee call for action is seen as a priority. However, strike activity beyond the control of the two major union confederations is significant in Spain. Strikes called by other unions tend to be associated with specific occupational groups, often in key positions in the production process. They usually enjoy strong bargaining power and perceive that the main confederations neglect their specific interests. Nevertheless, the Spanish labour laws have strongly favoured the representative status of the principal confederations.

The Spanish collective bargaining system is a hybrid between centralisation and decentralisation. That is, there are negotiations at the sector as well as at the firm level. Sector agreements can be of either national or regional scope and have to be negotiated by the major unions (UGT and CCOO, reaching separately at least a 10 percent of representatives in unions' elections) and the Spanish confederation of employers (CEOE, henceforth). National or regional sector agreements, because of applicability of the "automatic general effectiveness" principle, are minimum benchmarks for possible further negotiation at a firm specific level. Bargaining at firm level usually requires strong unionisation in the firm and as a result it does not take place very often in small and medium sized firms, so they end up being covered by the corresponding sector agreement. Additionally, union behaviour is likely to differ between sector and firm collective bargaining. For instance, at the sector level the union leaders feel lower pressure from the union rank and file than at the firm level. In the latter, they perceive a higher risk of being removed given the greater proximity of affiliates. Table 1 shows that the centralisation level has declined from 4 to 3, raising the relevance of sector-level against more central-level bargaining, but still far from levels 1 and 2 where firm/plant bargaining has a more important role. The Spanish level falls between the UK (maximum level of decentralisation) and Finland (maximum centralisation level).

Finally, coordination refers to the degree of consensus among collective bargaining partners (unions, employers and government). In Spain, the coordination degree is moderate (Table 1), and has generally declined since the 1980s according to the OECD measure. The general strike in December 1988 brought about the end of a period of widespread social consensus that had translated into several economic and social 
Esteve, Marco and Rochina / Revista de Economía Laboral 3 (2006), 14-45

pacts between the unions, employers and the government. Thus, the coordination degree fell from 4 in the 1980s to 3 in the 1990s. However, this OECD measure for the 1990s does not capture the consensus climate around the Spanish labour policy reform in 1997.

\section{Data and explanatory variables.}

The empirical analysis is carried out using registry data from the EHCP gathered by the Spanish Ministry of Labour and Social Affairs, for the period 1986-1999. It includes all strikes and lockouts taking place in Spain during that period. The party initiating the action is required to announce the occurrence of a strike or lockout to the labour authority (either the Ministry of Labour and Social Affairs or the Autonomous Community) by law. Then, this authority uses a questionnaire to collect information about the strike or lockout. In the empirical analysis we restrict attention to strikes, so lockouts are excluded.

There are a number of requirements for a strike to be included in the registry. First, it has to be a legal labour conflict. Thus, up to 1988, civil servants working for public administrations did not have the right to strike, so they were not included in the statistics. Further, members of the armed forces, military establishments or state security forces are forbidden to strike by law. Secondly, strikes must surpass a minimum threshold duration of, at least, one hour, either in one working day or accumulated over more working days. Finally, strikes not involving a lost in working days, such as slow-down strikes, or student and consumer strikes are not included.

The registry unit in the EHCP is the "strike-province-month". This definition of labour conflict is different to that used by the International Labour Organization (ILO, hereafter) that considers the "strike-call" as the conflict unit. According to the ILO definition, one strike is considered a unique conflict whenever it is called for by one individual or a group of them. In this paper we have arranged the data set to follow the definition of strike in the ILO. Therefore, the unit of analysis is each single strike, independently of its geographical (number of provinces involved) or temporal (total number of days) scope. Thus, the duration of a strike is the number of working days in which economic activity has been interrupted (for one hour, at least) from the date the strike began in the first economic unit involved (production unit where one or more persons work for the same firm) to the date it terminated in the last one.

The use of registry data has some advantages. First, strikes can be followed on a regular basis and under unified criteria since 1986 . The 
former series was interrupted at the end of 1985 . Thus, we examine strike duration of all the strikes beginning between the first of January 1986 and the $31^{\text {st }}$ of December 1999. Secondly, the large number of conflicts registered. After cleansing the data from general strikes ${ }^{9}$ and lockouts there are 14120 legal strikes. Of them, 14098 had concluded by the end of the sample period. Thirdly, the EHCP provides broad information regarding the characteristics of each strike. Fourthly, it allows distinguishing among different motives to strike (mainly, collective bargaining strikes and strikes arising from other causes). Fifthly, it includes strikes both in manufacturing and non manufacturing sectors. Finally, the EHCP also provides information on different strike outcomes (agreement and non-agreement), which is used in the competing risks analysis. However, some limitations of the data are related to the lack of information both on the bargaining process and on the firms in which strikes take place.

\section{Table 2: Variables definitions (Data source: EHCP unless otherwise indicated)}

Strike duration Number of working days of interruption in economic activity from the date the strike began in the first economic unit involved to the date it terminated in the last one.

Covariates (time-constant in survival analysis):

\begin{tabular}{ll} 
Industry & $\begin{array}{l}4 \text { dummy variables classifying strikes according to the branch of } \\
\text { economic activity in which the strike takes place: agriculture, } \\
\text { manufacturing, construction, and services. Strikes involving more } \\
\text { than one industry are classified according to the branch of } \\
\text { economic activity with the highest employment. }\end{array}$ \\
\hline Multi-province & $\begin{array}{l}\text { Dummy variable equal to one if the strike involves more than one } \\
\text { province, and zero otherwise. }\end{array}$ \\
\hline Autonomous & $\begin{array}{l}19 \text { dummy variables, one for each of the nineteen regional areas } \\
\text { Community }\end{array}$ \\
& $\begin{array}{l}\text { and Mutonomous Communities and } 2 \text { Autonomous Cities -Ceuta } \\
\text { if the strike took place in that region (in fact a strike can take place } \\
\text { in several regions at the same time), and zero otherwise. }\end{array}$ \\
\hline Type of units affected & $\begin{array}{l}4 \text { dummy variables classifying strikes according to: inferior level to } \\
\text { the firm, all firm workplaces, group of firms belonging to the same } \\
\text { group, and sector level. }\end{array}$ \\
\hline Number of strikers & $\begin{array}{l}\text { 4 dummy variables classifying strikes according to the maximum } \\
\text { number of workers that took part during the course of the } \\
\text { stoppage, even if some workers participated for only part of the }\end{array}$
\end{tabular}

${ }^{9}$ It does not make sense the analysis of general strikes duration given that they last one day. 


\begin{tabular}{|c|c|}
\hline & $\begin{array}{l}\text { duration, excluding legal minimum services: fewer than } 29,29-84 \text {, } \\
85-290 \text {, and more than } 290 \text {. }\end{array}$ \\
\hline Support & $\begin{array}{l}\text { Ratio between the maximum number of workers that took part } \\
\text { during the course of the stoppage and the workforce of the } \\
\text { workplaces involved in the strike. }\end{array}$ \\
\hline Minimum services & $\begin{array}{l}\text { Dummy variable that takes value one if minimum services were } \\
\text { applied, and zero otherwise. }\end{array}$ \\
\hline Cause of dispute & $\begin{array}{l}6 \text { dummy variables classifying strikes according to: disputes } \\
\text { arising from collective bargaining; labour-related disputes; } \\
\text { concerning trade union; sympathetic; social and economic policies; } \\
\text { other non-labour disputes. }\end{array}$ \\
\hline $\begin{array}{l}\text { Party initiating the } \\
\text { action }\end{array}$ & $\begin{array}{l}6 \text { dummy variables classifying strikes according to: strike call by } \\
\text { group of workers; delegates/enterprise committee; trade union } \\
\text { UGT; trade union CCOO; other trade unions; other parties } \\
\text { (neighbourhood assemblies, politic formations, etc.). }\end{array}$ \\
\hline $\begin{array}{l}\text { Type of applicable } \\
\text { collective agreement }\end{array}$ & $\begin{array}{l}6 \text { dummy variables classifying strikes according to: plant } \\
\text { agreement, firm, group of firms, sector, several collective } \\
\text { agreements, and non-existent collective agreement. }\end{array}$ \\
\hline $\begin{array}{l}\text { Type of institutional } \\
\text { sect. }\end{array}$ & $\begin{array}{l}4 \text { dummy variables classifying strikes according to: private } \\
\text { company; public company; public administration; other (private } \\
\text { and public companies or several institutional sectors). }\end{array}$ \\
\hline Legal reform 1992 & $\begin{array}{l}\text { Indicator variable coded one if the strike began in } 1992 \text { or later and } \\
\text { zero otherwise. }\end{array}$ \\
\hline Legal reform 1997 & $\begin{array}{l}\text { Indicator variable coded one if the strike began in } 1997 \text { or later and } \\
\text { zero otherwise. }\end{array}$ \\
\hline $\begin{array}{l}\text { Real GDP growth } \\
\text { rate }\end{array}$ & $\begin{array}{l}\text { Annual growth rate of real GDP of the year in which the strikes } \\
\text { began. Source: INE }\end{array}$ \\
\hline Unemployment rate & $\begin{array}{l}\text { Annual unemployment rate of the year in which the strikes began. } \\
\text { Source: INE }\end{array}$ \\
\hline Inflation rate $(\mathrm{t}-1)$ & $\begin{array}{l}\text { Inflation rate in the previous year in which the strikes began. } \\
\text { Source: INE }\end{array}$ \\
\hline
\end{tabular}

In order to make the analysis richer and to test for empirical implications of theoretical models we enlarge our information set with additional variables, such as the unemployment rate, the real GDP growth rate and inflation rate, obtained from official statistical sources (National Statistics Institute, INE). Hence, the explanatory variables (or covariates) in our empirical specification (see Table 2 for variables definition) include the type of industry; the geographical scope; the type of units affected; the number of strikers; the existence of minimum services; the cause of dispute; the party initiating the action; the type of collective agreement applicable; the type of institutional sector; policy variables; business cycle, and unions' information for negotiations. 


\section{Methodology.}

The empirical analysis is carried out using duration methods, which allow accounting for different strike outcomes. These methods take into account the evolution over time of the risk of ending a strike and of its determinants since they control for both the occurrence and the timing of ending. Furthermore, duration methods are suitable in the presence of right censoring, when we only know that the strike has lasted at least for a certain period of time.

The central concept in duration analysis is the hazard rate. Following Kalbfleisch and Prentice (1980), this is defined as the probability that a strike ends in a moment $t$ conditional upon survival up to that time $t$, and conditional on a vector $X_{i}$ of covariates:

$$
\lambda\left(t ; X_{i}\right)=\lim _{d t \rightarrow 0} \frac{\operatorname{Pr}\left[t \leq T<t+d t / T \geq t, X_{i}\right]}{d t}
$$

where $T$ is a non-negative random variable (duration), which is assumed to be continuous. Hence, $\lambda_{i}(t)$ is an instantaneous ending rate.

In order to examine the determinants of strike durations in different strike outcomes, we analyse the effect of a set of explanatory variables on the ending rates. The multivariate analysis of strike duration is carried out by estimating semi-parametric proportional hazard models for the single risk of ending a strike and for the competing risks model. The estimations are performed using the semi-parametric Cox Proportional Hazard Model (CPHM, henceforth) proposed by Cox (1972, 1975).

Duration methods can be extended to the analysis of situations where there are different strike outcomes, namely, agreement and nonagreement. Consequently, we are interested in examining whether the ending determinants differ depending on the outcome. Dealing with different ending routes only requires the competing risks be mutually exclusive and exhaustive (that is, a strike cannot end in agreement and non-agreement at once). Let us suppose that strike $i$ is at risk for $K$ different types of events, i.e. it faces $K$ competing risks (agreement and non-agreement). Therefore, each strike $i$ has a (latent) corresponding duration associated with each event type $T_{i 1}, \ldots, T_{i K}$ and a corresponding hazard function $\lambda_{i k}(t)(k=1, \ldots, K)$, and we observe the shortest duration: $T_{i}=\min \left\{T_{i 1}, \ldots, T_{i K}\right\}$. We make the usual assumption of independent competing risks (Narendranathan and Stewart, 1991), which simplifies the estimation procedure. Thus, the log-likelihood for the competing risks

model is additively separable into $K$ terms, each one being a function of 
the parameters of a single outcome-specific hazard. Thus, in order to estimate these models we must proceed with the estimation of single risk hazards (for instance, risk 1 out of $K$ ) considering durations finishing by different outcomes than the one of interest as censored at the point of completion. Therefore, we estimate the following models:

$$
\begin{aligned}
& \lambda_{i k}(t)=\lambda_{0 k}(t) \exp \left(X_{i k}^{\prime} \times \beta_{k}\right) \quad \text { Competing risk model } \\
& k=\{\text { agreement; non agreement }\}
\end{aligned}
$$

where $\lambda_{o}(t)$ is an unspecified baseline function obtained for values of the covariates equal to zero, and $\beta$ is a vector of unknown parameters. In this specification, the effect of the independent variables is a parallel shift of the baseline function, which is estimated for all those strikes reaching certain duration.

Parameters are consistently estimated by maximization of a partial likelihood function (Cox, 1975), which does not depend on the baseline function. Partial likelihood works in terms of the ordering of outcomes and conditional probabilities. Let $T_{1}, \ldots, T_{N}$ be $N$ possibly rightcensored ending times and $X_{1}, \ldots, X_{N}$ be the corresponding explanatory variables vector where $X_{j}$ is observed on $\left[0, T_{j}\right]$. Therefore, the maximum partial likelihood estimator is the value that maximizes the partial likelihood function:

$$
L(\beta)=\prod_{j=1}^{N}\left[\frac{\exp \left(X^{\prime}{ }_{j}\left(T_{j}\right) \beta\right)}{\sum_{h \in R_{j}} \exp \left(X^{\prime}{ }_{h}\left(T_{j}\right) \beta\right)}\right]^{c_{j}}
$$

where $R_{j}$ is the set of strikes at risk at duration time $T_{j}$ and $c_{j}$ is an indicator variable that takes value 1 if $T_{j}$ is an observed ending time and value 0 otherwise. We use the method proposed by Breslow (1974) for handling "ties" (i.e., strikes suffering the outcome $k$ in the same period).

Narendranathan and Stewart (1991) provide a test of whether different ending types are behaviourally distinct (rather than simply incidental) for continuous time proportional hazard models. Hence, we carry out a test of equality of all parameters except intercepts in the models for the destination-specific hazards. This is a test of the hypothesis that the outcome-specific hazards are all proportional to one another (i.e. that all parameters except the intercepts are equal across the hazards). The test statistic is:

$$
L R=2\left[\ln \left(L_{C R}\right)-\ln \left(L_{S R}\right)-\sum_{k=1}^{K} n_{k} \times \ln \left(\frac{n_{k}}{\sum_{k=1}^{K} n_{k}}\right)\right]
$$


where $\ln \left(\mathrm{L}_{\mathrm{CR}}\right)$ is the maximised log-likelihood from the competing risk model (the sum of those from the component models), $\ln \left(\mathrm{L}_{\mathrm{SR}}\right)$ is the maximised log-likelihood from the single-risk model; $\mathrm{n}_{\mathrm{k}}$ is the number of endings in state $k$, with $K$ representing all the competing risks -i.e. all the strike outcomes-. The test statistic is a $\chi^{2}$ with degrees of freedom equal to the number of restrictions (that is, the number of covariates). If we cannot reject the null hypothesis, then the risks are not different, indicating that the ending outcomes are essentially random with respect to the covariates and baseline hazards.

\section{Estimation results.}

Table 3 displays the pattern of strike activity in Spain over 19861999. There is a noticeable pattern of decline in the number of strikes since 1991, particularly from 1994 onwards. Table 3 also shows mean duration of strikes. The average duration is of 5.75 days and the median duration is of 3 days. Further, 45.09 percent of the strikes end with agreement and 53.85 percent without reaching an agreement. ${ }^{10}$ On average, strikes ending in agreement show longer durations (6.14 days versus 5.31 days for strikes ending without agreement) and share the same median duration (3 days). It can be due to the need to invest a longer time in negotiations to find out the relevant information to reach an agreement, according to predictions from asymmetric and private information models. In strikes ending with agreement 50 percent of them end because of workers' decision whereas 29 percent do so because of expiration of the fixed time in the strike call. However, strikes ending without agreement are more biased to finish because of expiration of the fixed time in the strike call (71 percent versus 25 percent due to workers' decision). In those strikes ending without agreement, the situation of workers continues at pre-strike levels. With agreement, workers' claims are partially or totally achieved, changing then their conditions with respect to the pre-strike levels. Results from a conventional probit model to analyse the determinants of the strike agreement outcome versus nonagreement can be found in Table 4. In what follows, we will discuss the probit results along with those from the duration analysis (Table 5).

\footnotetext{
10 During the analysed time period, lockout strike outcomes represented only $1.06 \%$ of total strikes, and because of lack of enough variation in some of the explanatory variables, which gives rise to statistically non-significant coefficient estimates, we have excluded them from our analysis. A cursory examination suggests that strikes ending in lockouts were longer than the remaining strikes (mean duration 10.94 days and median duration 6 days).
} 
Table 3: Number of strikes/year and duration, by ending outcome

\begin{tabular}{cccccccccc}
\hline & \multicolumn{3}{c}{ All strikes } & \multicolumn{3}{c}{ Agreement } & \multicolumn{3}{c}{ Non-agreement } \\
\hline Year & $\begin{array}{c}\text { Number of } \\
\text { strikes }\end{array}$ & $\%$ & $\begin{array}{c}\text { Mean } \\
\text { duration }\end{array}$ & $\begin{array}{c}\text { Number of } \\
\text { Strikes }\end{array}$ & $\%$ & $\begin{array}{c}\text { Mean } \\
\text { duration }\end{array}$ & $\begin{array}{c}\text { Number of } \\
\text { strikes }\end{array}$ & $\%$ & $\begin{array}{c}\text { Mean } \\
\text { Duration }\end{array}$ \\
\hline 1986 & 869 & 6,16 & 5,95 & 522 & 8,21 & 5,69 & 327 & 4,31 & 6,09 \\
1987 & 1468 & 10,41 & 5,75 & 651 & 10,24 & 5,34 & 797 & 10,50 & 5,18 \\
1988 & 1175 & 8,33 & 5,27 & 377 & 5,93 & 6,72 & 788 & 10,38 & 4,50 \\
1989 & 1036 & 7,35 & 5,04 & 409 & 6,43 & 5,97 & 616 & 8,11 & 4,49 \\
1990 & 1207 & 8,56 & 5,72 & 493 & 7,76 & 7,21 & 708 & 9,33 & 4,49 \\
1991 & 1486 & 10,54 & 5,16 & 781 & 12,29 & 5,44 & 699 & 9,21 & 4,84 \\
1992 & 1260 & 8,94 & 5,50 & 562 & 8,84 & 5,15 & 686 & 9,04 & 5,55 \\
1993 & 1110 & 7,87 & 6,08 & 492 & 7,74 & 6,92 & 609 & 8,02 & 5,40 \\
1994 & 864 & 6,13 & 6,38 & 408 & 6,42 & 6,28 & 446 & 5,87 & 6,39 \\
1995 & 847 & 6,01 & 6,59 & 375 & 5,90 & 6,07 & 470 & 6,19 & 7,02 \\
1996 & 781 & 5,54 & 6,50 & 369 & 5,80 & 6,96 & 398 & 5,24 & 5,78 \\
1997 & 687 & 4,87 & 5,65 & 318 & 5,00 & 5,13 & 356 & 4,69 & 6,04 \\
1998 & 596 & 4,23 & 5,68 & 273 & 4,29 & 5,93 & 313 & 4,12 & 5,16 \\
1999 & 712 & 5,05 & 6,01 & 327 & 5,14 & 6,65 & 379 & 4,99 & 5,49 \\
TOTAL & 14098 & 100 & 5,75 & 6357 & 100 & 6,14 & 7592 & 100 & 5,31 \\
Distribution & $100 \%$ & & Median=3 & $45,09 \%$ & & Median=3 & $53,85 \%$ & & Median=3 \\
\hline
\end{tabular}

Note: Excludes non-ended strikes by 31st December 1999 (22 strikes).

In Table 5 we report the main results obtained from the estimation of equations (2). The estimated models are continuous time CPHM estimated maximising a partial likelihood function with respect to the vector of coefficients $\beta$ without the need to estimate the baseline functions. A unit change in a variable leads to a proportional shift, constant across (duration) time, in the conditional probability of suffering the analysed event (a strike ending). The effect of the covariates is reported by the hazard ratios. A value smaller (greater) than one implies a negative (positive) effect on the hazard rate. The baseline functions can be recovered non-parametrically and their shapes are depicted in Figure 1. Given that only one percent of our strikes last longer than 53 days, Figure 1 displays a pattern of negative duration dependence independently of the strike outcome, that is, the risk of ending a strike decreases with duration. ${ }^{11}$

11 The theoretical war-of-attrition bargaining models for strikes predict negative duration dependence (see Kennan and Wilson, 1989). 
Table 4: Probit estimates. Dependent variable: Agreement

\begin{tabular}{|c|c|c|}
\hline & Coefficient & $\mathrm{P}$-value \\
\hline \multicolumn{3}{|l|}{ Industry (Agriculture omitted) } \\
\hline Manufacturing & $-0.2865^{* * *}$ & 0.004 \\
\hline Construction & 0.0145 & 0.895 \\
\hline Services & $-0.2569 * * *$ & 0.010 \\
\hline Multi-province & $-0.1492^{* *}$ & 0.039 \\
\hline \multicolumn{3}{|l|}{ Autonomous Community } \\
\hline Andalucia & $-0.2354^{* * *}$ & 0.000 \\
\hline Aragon & $-0.2058^{* * *}$ & 0.001 \\
\hline Asturias & $0.3553^{* * *}$ & 0.000 \\
\hline Canarias & $0.3282^{* * *}$ & 0.000 \\
\hline Cantabria & $0.5297 * * *$ & 0.000 \\
\hline Castilla_Leon & $-0.3053^{* * *}$ & 0.000 \\
\hline Castilla-La Mancha & $-0.1758^{* * *}$ & 0.008 \\
\hline Catalunya & $-0.6147 * * *$ & 0.000 \\
\hline Madrid & $-0.0666^{*}$ & 0.069 \\
\hline Com. Valenciana & 0.0019 & 0.964 \\
\hline Extremadura & 0.0263 & 0.787 \\
\hline Galicia & $-0.1224^{* * *}$ & 0.009 \\
\hline Islas Baleares & 0.1132 & 0.304 \\
\hline Navarra & -0.0297 & 0.599 \\
\hline Pais Vasco & $0.0674 *$ & 0.072 \\
\hline La Rioja & $-0.2259 * *$ & 0.043 \\
\hline Murcia & $0.3216^{* * *}$ & 0.000 \\
\hline Ceuta & $-0.5138 * * *$ & 0.007 \\
\hline Melilla & 0.0919 & 0.625 \\
\hline \multicolumn{3}{|l|}{$\begin{array}{l}\text { Type of units affected } \\
\text { (workplaces within an enterprise omitted) }\end{array}$} \\
\hline Enterprise & $-0.2070 * * *$ & 0.000 \\
\hline Group of enterprises & -0.0477 & 0.631 \\
\hline Sector & -0.0032 & 0.947 \\
\hline \multicolumn{3}{|l|}{ Number of strikers (fewer than 29 omitted) } \\
\hline 29 to 84 & $-0.1195^{* * *}$ & 0.000 \\
\hline $85-290$ & $-0.1346^{* * *}$ & 0.000 \\
\hline More than 290 & $-0.3573^{* * *}$ & 0.000 \\
\hline Support & $0.3134 * * *$ & 0.000 \\
\hline Minimum services & $0.1182^{* * *}$ & 0.000 \\
\hline \multicolumn{3}{|l|}{$\begin{array}{l}\text { Cause of dispute } \\
\text { (arising from collective bargaining omitted) }\end{array}$} \\
\hline Labour-related disputes & $-0.1922^{* * *}$ & 0.000 \\
\hline Disputes concerning trade union issues & $-0.4476 * * *$ & 0.010 \\
\hline Sympathetic disputes & $-0.3880 * * *$ & 0.000 \\
\hline Prompted by economic and social policy & $-0.4471 * * *$ & 0.000 \\
\hline Other non-labour disputes & $-0.4440 * * *$ & 0.000 \\
\hline
\end{tabular}


Party initiating the action (group-of-workers omitted)

Delegates/enterprise committee

$\begin{array}{ll}-0.0977^{* * *} & 0.010 \\ 0.0427 & 0.373 \\ -0.0809^{*} & 0.093 \\ -0.1314^{* *} & 0.037 \\ 0.0043 & 0.959\end{array}$

Type of applicable collective agreement

(workplace omitted)

Enterprise

Group of enterprises

Sector

Several collective agreements

Non-existent collective agreement

Type of institutional sector (private company omitted)

Public company

Public administration

Others

Legal reform 1992

Legal reform 1997

Unemployment rate

Real GDP growth rate

Inflation rate $(\mathrm{t}-1)$

\begin{tabular}{lr}
-0.0512 & 0.314 \\
-0.0986 & 0.288 \\
-0.0390 & 0.448 \\
$-0.5975 * * *$ & 0.000 \\
-0.0669 & 0.294 \\
& \\
$-0.2357^{* * * *}$ & 0.000 \\
$-0.1522^{* * *}$ & 0.007 \\
$-0.1630^{* *}$ & 0.044 \\
-0.0438 & 0.470 \\
$0.4157^{* * *}$ & 0.000 \\
0.0101 & 0.117 \\
$-0.0439 * * *$ & 0.000 \\
$0.0677^{* * *}$ & 0.000 \\
0.0995 & 0.549 \\
\hline & -8921.6755 \\
$c$ & 0.072 \\
$c$ & 13949 \\
\hline
\end{tabular}

Log pseudo-likelihood

Wald (Chi-square)

Pseudo R2

13949

Number of observations

$\left({ }^{* * *}\right),(* *)$, and $(*)$, means statistically different from zero at the one, five, and ten-percent significance level.

The regression results reported in Table 5 are discussed in turn. In order to highlight the effect of allowing for different ending routes, we present results from single hazard estimates in which the two ending types are pooled, and results from competing risks specifications in which endings with agreement and non-agreement are treated as competing ending routes. The results from specification errors tests indicate that we cannot reject the null hypothesis that the model is correctly specified. We reject (at a 1 percent of statistical significance) the null hypothesis that the different strike outcomes are behaviourally equal (Test of Proportionality of Risks proposed by Narendranathan and Stewart, 1991). We should then estimate separated coefficients corresponding to the two differentiated risks. 
Table 5: Strike duration in Spain, 1986-99. Cox Proportional Hazards Model

\begin{tabular}{|c|c|c|c|c|c|c|}
\hline & \multicolumn{2}{|c|}{ Single risk ending } & \multicolumn{2}{|c|}{ Agreement } & \multicolumn{2}{|c|}{ Non-agreement } \\
\hline & $\begin{array}{c}\text { Hazard } \\
\text { ratio }\end{array}$ & $\mathrm{P}$-value & $\begin{array}{c}\text { Hazard } \\
\text { ratio }\end{array}$ & $\mathrm{P}$-value & $\begin{array}{c}\text { Hazard } \\
\text { Ratio }\end{array}$ & P-value \\
\hline \multicolumn{7}{|l|}{ Industry (Agriculture omitted) } \\
\hline Manufacturing & $1.2308^{* * *}$ & 0.007 & 1.0182 & 0.857 & $1.5821^{* * *}$ & 0.000 \\
\hline Construction & 1.0364 & 0.670 & 1.0951 & 0.406 & 1.0519 & 0.703 \\
\hline Services & $1.1542^{*}$ & 0.061 & 0.9640 & 0.715 & $1.4641^{* * *}$ & 0.002 \\
\hline Multi-province & 0.9808 & 0.703 & $0.7728^{* * *}$ & 0.006 & 1.0337 & 0.595 \\
\hline \multicolumn{7}{|l|}{ Autonomous Community } \\
\hline Andalucia & $1.0463^{*}$ & 0.069 & $0.8768^{* * *}$ & 0.001 & $1.2368^{* * *}$ & 0.000 \\
\hline Aragon & 1.0405 & 0.409 & $0.8495^{* *}$ & 0.035 & $1.2226^{* * *}$ & 0.001 \\
\hline Asturias & $1.1214^{* * *}$ & 0.001 & $1.5363^{* * *}$ & 0.000 & $0.8808^{* * *}$ & 0.011 \\
\hline Canarias & 0.9927 & 0.877 & $1.2625^{* * *}$ & 0.000 & $0.7935^{* * *}$ & 0.001 \\
\hline Cantabria & $0.8934^{* *}$ & 0.037 & $1.2539 * * *$ & 0.001 & $0.6063^{* * *}$ & 0.000 \\
\hline Castilla_Leon & $1.1470^{* * *}$ & 0.000 & $0.8704^{* * *}$ & 0.006 & $1.3674^{* * *}$ & 0.000 \\
\hline Castilla-La Mancha & $1.0895^{*}$ & 0.085 & 0.9465 & 0.481 & $1.2312^{* * *}$ & 0.002 \\
\hline Catalunya & $1.0898^{* * *}$ & 0.002 & $0.6115^{* * *}$ & 0.000 & $1.5582^{* * *}$ & 0.000 \\
\hline Madrid & $1.1280^{* * *}$ & 0.000 & $1.1027 * *$ & 0.023 & $1.1742^{* * *}$ & 0.000 \\
\hline Com. Valenciana & 0.9785 & 0.495 & 0.9900 & 0.835 & 0.9407 & 0.165 \\
\hline Extremadura & $0.8765^{*}$ & 0.060 & 0.8976 & 0.305 & $0.8524^{*}$ & 0.092 \\
\hline Galicia & 0.9828 & 0.619 & $0.8909 * *$ & 0.029 & 1.0748 & 0.129 \\
\hline Islas Baleares & 0.9737 & 0.723 & 1.2078 & 0.110 & 0.9421 & 0.525 \\
\hline Navarra & 0.9835 & 0.700 & 0.9412 & 0.362 & 1.0304 & 0.607 \\
\hline País Vasco & 1.0216 & 0.449 & $1.0875^{* *}$ & 0.043 & 0.9773 & 0.561 \\
\hline La Rioja & 1.1348 & 0.112 & 0.8822 & 0.374 & $1.2491^{* *}$ & 0.027 \\
\hline Murcia & $0.8696^{* *}$ & 0.018 & $1.1502^{*}$ & 0.081 & $0.6809^{* * *}$ & 0.000 \\
\hline Ceuta & $1.2929^{*}$ & 0.056 & 0.7085 & 0.184 & $1.7418^{* * *}$ & 0.001 \\
\hline Melilla & 0.8078 & 0.114 & 0.9916 & 0.973 & $0.7459^{*}$ & 0.074 \\
\hline \multicolumn{7}{|l|}{$\begin{array}{l}\text { Type of units affected } \\
\text { (workplaces within an enterprise } \\
\text { omitted) }\end{array}$} \\
\hline Enterprise & $0.9418^{* * *}$ & 0.003 & $0.7917 * * *$ & 0.000 & $1.1117^{* * *}$ & 0.000 \\
\hline Group of enterprises & 1.0698 & 0.377 & 1.0333 & 0.772 & 1.1326 & 0.235 \\
\hline Sector & $0.8906^{* * *}$ & 0.002 & $0.9032^{*}$ & 0.059 & $0.9095^{*}$ & 0.068 \\
\hline \multicolumn{7}{|l|}{$\begin{array}{l}\text { Number of strikers } \\
\text { (fewer than } 29 \text { omitted) }\end{array}$} \\
\hline 29 to 84 & $1.2042^{* * *}$ & 0.000 & $1.1050^{* * *}$ & 0.005 & $1.3095^{* * *}$ & 0.000 \\
\hline $85-290$ & $1.2671^{* * *}$ & 0.000 & $1.1435 * * *$ & 0.000 & $1.4016^{* * *}$ & 0.000 \\
\hline More than 290 & $1.4308^{* * *}$ & 0.000 & 1.0572 & 0.204 & $1.8445^{* * *}$ & 0.000 \\
\hline Support & $0.7385^{* * *}$ & 0.000 & 0.9296 & 0.154 & $0.5983^{* * *}$ & 0.000 \\
\hline Minimum services & $0.8611^{* * *}$ & 0.000 & 0.9468 & 0.152 & $0.8063^{* * *}$ & 0.000 \\
\hline \multicolumn{7}{|l|}{$\begin{array}{l}\text { Cause of dispute } \\
\text { (arising from collective bargaining } \\
\text { omitted) }\end{array}$} \\
\hline Labour-related disputes & 1.0053 & 0.795 & $0.8439 * * *$ & 0.000 & $1.1578^{* * *}$ & 0.000 \\
\hline Disputes on trade union issues & 1.1958 & 0.175 & 0.7404 & 0.184 & $1.7740^{* * *}$ & 0.000 \\
\hline Sympathetic disputes & $1.5416^{* * *}$ & 0.000 & 1.0917 & 0.391 & $2.0317^{* * *}$ & 0.000 \\
\hline
\end{tabular}




\begin{tabular}{|c|c|c|c|c|c|c|}
\hline Economic and social policy & $1.1556^{* *}$ & 0.017 & $0.7825^{* *}$ & 0.020 & $1.5180^{* * *}$ & 0.000 \\
\hline Other non-labour disputes & $1.1774^{* *}$ & 0.032 & $0.7983^{*}$ & 0.082 & $1.6097^{* * *}$ & 0.000 \\
\hline \multicolumn{7}{|l|}{$\begin{array}{l}\text { Party initiating the action (group-of- } \\
\text { workers omitted) }\end{array}$} \\
\hline \multicolumn{7}{|l|}{ Delegates/enterprise } \\
\hline Trade union UGT & 1.0497 & 0.175 & 1.0833 & 0.121 & 1.0285 & 0.576 \\
\hline Trade union $\mathrm{CCOO}$ & $1.0820 * *$ & 0.030 & 0.9932 & 0.897 & $1.1617^{* * *}$ & 0.003 \\
\hline Other trade unions & $0.8995^{* *}$ & 0.024 & $0.8007 * * *$ & 0.002 & 0.9839 & 0.798 \\
\hline Other parties & 0.9475 & 0.378 & 0.9647 & 0.691 & 0.8983 & 0.210 \\
\hline \multicolumn{7}{|l|}{$\begin{array}{l}\text { Type of applicable collective agreement } \\
\text { (workplace omitted) }\end{array}$} \\
\hline Enterprise & 1.0153 & 0.700 & 0.9943 & 0.917 & 1.0505 & 0.388 \\
\hline Group of enterprises & 0.9795 & 0.778 & 0.9399 & 0.562 & 1.0513 & 0.625 \\
\hline Sector & 0.9845 & 0.694 & 0.9769 & 0.677 & 1.0268 & 0.648 \\
\hline $\begin{array}{l}\text { Several collective agreements } \\
\text { Non-existent collective }\end{array}$ & $1.2715^{* *}$ & 0.024 & 0.6662 & 0.102 & $1.6267^{* * *}$ & 0.000 \\
\hline agreement & $0.9180^{*}$ & 0.080 & 0.8967 & 0.124 & 0.9620 & 0.573 \\
\hline \multicolumn{7}{|l|}{$\begin{array}{l}\text { Type of institutional sector (private } \\
\text { company omitted) }\end{array}$} \\
\hline Public company & $1.2763^{* * *}$ & 0.000 & 1.0668 & 0.157 & $1.4879^{* * *}$ & 0.000 \\
\hline Public administration & $1.3421^{* * *}$ & 0.000 & $1.1985^{* * *}$ & 0.008 & $1.4741^{* * *}$ & 0.000 \\
\hline Others & $1.1693^{* *}$ & 0.011 & 1.0065 & 0.948 & $1.3031^{* * *}$ & 0.001 \\
\hline Legal reform 1992 & 1.0051 & 0.914 & 0.9771 & 0.739 & 1.0419 & 0.525 \\
\hline Legal reform 1997 & 0.9742 & 0.534 & $1.3578^{* * *}$ & 0.000 & $0.7288^{* * *}$ & 0.000 \\
\hline Unemployment rate & 0.9979 & 0.671 & 1.0055 & 0.457 & 0.9895 & 0.128 \\
\hline Real GDP growth rate & 0.9966 & 0.680 & $0.9594^{* * *}$ & 0.001 & $1.0272^{* *}$ & 0.022 \\
\hline Inflation rate $(\mathrm{t}-1)$ & 0.9890 & 0.179 & $1.0436^{* * *}$ & 0.001 & $0.9467^{* * *}$ & 0.000 \\
\hline Log-likelihood & \multicolumn{2}{|c|}{-121858.2} & \multicolumn{2}{|c|}{-54380.883} & \multicolumn{2}{|c|}{-65615.831} \\
\hline Chi-square (d.f.) & \multicolumn{2}{|c|}{$969.34(54)$} & \multicolumn{2}{|c|}{$725.38(54)$} & \multicolumn{2}{|c|}{$1575.79(54)$} \\
\hline Number of strikes & \multicolumn{2}{|c|}{14120} & \multicolumn{2}{|c|}{14120} & \multicolumn{2}{|c|}{14120} \\
\hline Number of ending strikes & \multicolumn{2}{|c|}{14098} & \multicolumn{2}{|c|}{6357} & \multicolumn{2}{|c|}{7592} \\
\hline
\end{tabular}

$\left({ }^{* * *}\right),(* *)$, and $(*)$, means statistically different from zero at the one, five, and ten-percent significance level.

\section{Industry}

We find that strikes in manufacturing and services are significantly shorter than those in construction and agriculture and fishery, both for pooled strikes and strikes ending with non agreement (Table 5), and also more likely to end without agreement (probit results, Table 4). Thus, after a strike in manufacturing and services it is more likely that workers end up with pre-strike conditions. 


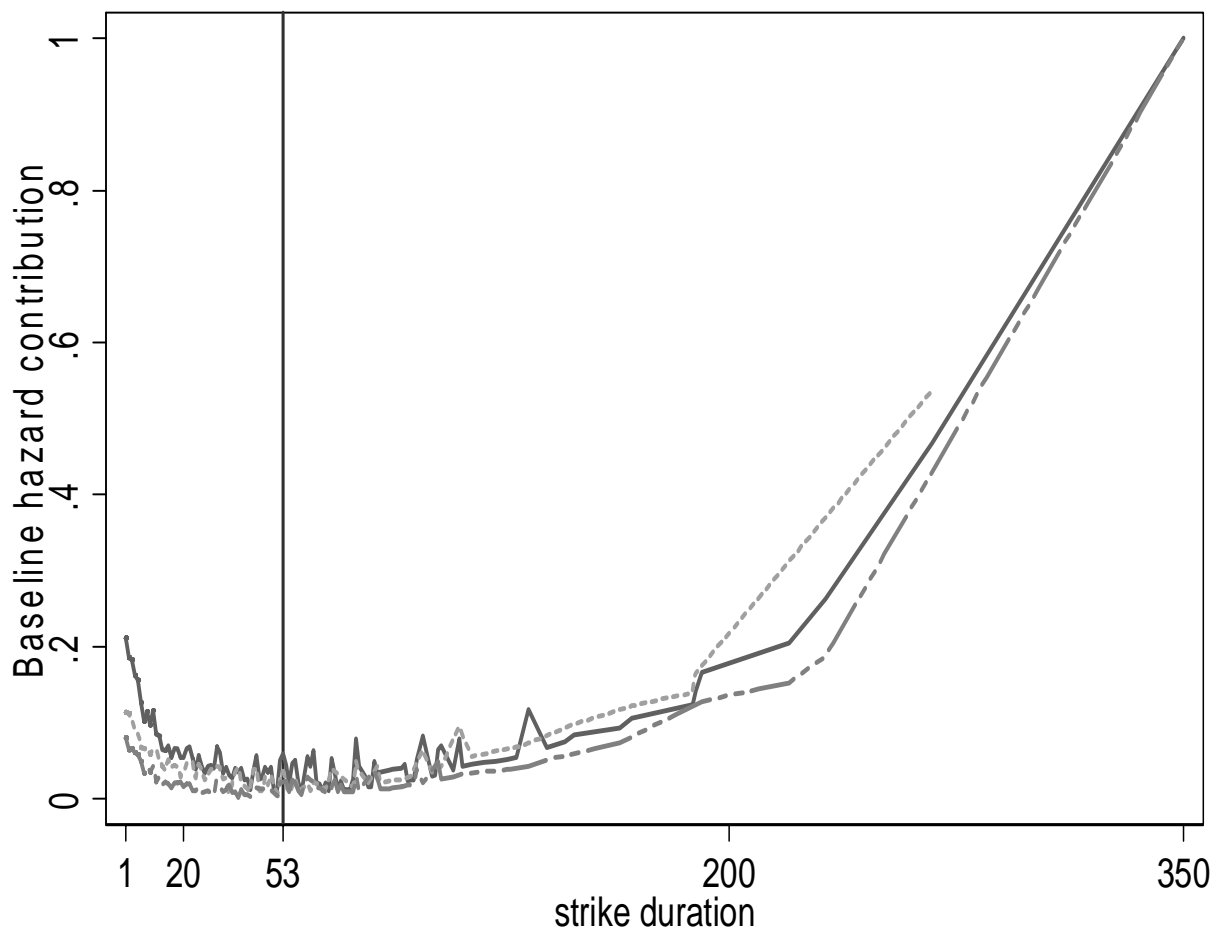

Figure 1: Duration Dependence Pattern

\section{Geographical scope}

Two variables control for this dimension of the strike: Multiprovince and Autonomous Community. Multi-province accounts for the fact that the geographical scope of the strike may go beyond the province. The Multi-province variable contributes to explain longer durations in strikes ending with agreement (Table 5), and it increases the probability of ending without agreement (Table 4). Given that in Spain there has been a high presence of unions at provincial levels, with this variable we try to capture the effects of the higher amount of organization at this level (in comparison to multiple provinces involve) on strike duration and the 
probability of reaching an agreement. Autonomous Community is just a control variable to distinguish among different autonomous communities.

\section{Type of units affected}

A strike can take place in some (but not all) of a firm workplaces, in all firm workplaces, in a group of firms belonging to the same group, or at a sector level. In relation to this variable (Table 5) we find for the pooled and agreement cases that strikes taking place in the whole firm or sector have longer durations than those affecting some of the firm workplaces or a group of firms. For the case of non-agreement endings, the strikes which take place in the whole firm dimension are significantly shorter and those at the sector level are significantly longer. What can explain the general result of longer durations associated to sector strikes? Probably, as we already mentioned, sector agreements should be negotiated by the major unions (UGT and CCOO) and the CEOE, and they are considered as the starting point for negotiations at a lower level (for instance, firm level). Consequently, unions should be very much interested in establishing, as much as possible, these minimum benchmarks for future negotiations. On the other hand, what can explain longer durations for firm level strikes ending with agreement and shorter durations for firm level strikes ending without agreement? As also mentioned before, bargaining at firm level usually requires strong unionization and then it has associated bigger union resistance facilitating the union to endure a longer strike when is looking for an agreement outcome. However, a strong union can anticipate faster the type of firm, in relation to rents, that is facing (in particular a low rent firm) and then finding it difficult to reach an agreement to decide to stop the strike earlier. The previous arguments may explain the behaviour in large firms. On the contrary, arguments based on solidarity and cohesion of workers facing a labour conflict may be behind the behaviour in small firms. Finally, we find firm strikes to have a higher probability of ending in non agreement (Table 4). This final result can be explained by the fact that workers will be then probably covered by the corresponding sector agreement, which represents an outside option for them.

\section{Strike size}

The number of strikers has been extensively considered in related empirical literature. As already noticed by Cramton et al. (1999a, 1999b), empirical work suggests that strikes which are initiated with strong support are resolved more quickly. The theoretical background for this 
finding comes mainly from the firm side. Larger bargaining units are expected to be relatively more effective in reducing the firm's profitability during a strike both by imposing more production inefficiencies and higher operating costs on the firm during the strike. Thus, the firm would like to settle faster. In our results (Table 5), and according to the theory, the variable Number of strikers generally increases all the risks of ending a strike, that is, a lower number of strikers is associated to longer durations. Furthermore, a smaller number of strikers decrease the probability of ending a strike in non agreement. This last result could be due to the fact that a small number of strikers could be associated with key specific occupational groups with strong bargaining power (such as pilots or airports controllers). Once the number of strikers is controlled for, a higher fraction of employees following the strike (the support variable) may reflect a higher support to the strike call and to the strike caller, what would strength its bargaining position probably contributing to lengthen the strike. Our findings confirm this result given that we find that the more support the longer the duration of the strike, especially in the case of ending without agreement.

\section{Minimum services}

Unlike in other countries, provision for minimum services in Spain is determined by government decrees without consultation to unions. They have the effect of alleviating the strike costs on customers, workers and employers. This is the main figure in the Spanish industrial relation system to reduce strike costs, as replacement workers and subsidies to strikers do not exist. As stated above, an empirical implication of some economic theories on strike activity is that strikes should occur for shorter periods when the costs of the strike are higher (Hicks, 1932; Kennan, 1980; Reder and Neumann, 1980). Then, the presence of minimum services is expected to be linked to longer durations. Our results show up this expectations because when the variable Minimum services is significant (pooled and non agreement situations) this variable predicts longer durations (Table 5). It also contributes to diminish the probability of ending the strike with non agreement (Table 4). The latter result may be explained also by a higher pressure from the government not only to finish the strike earlier but to reach an agreement in strikes where the government has already judged the necessity to provide minimum services. 


\section{Cause of dispute}

Reaching an agreement is expected to be more difficult whenever there are many different issues involved in a bargaining process, which imply high information problems and bargaining costs. Thus, disputes arising from collective bargaining, with more complex protocols, are likely to be associated to longer durations, as pointed out by Reder and Neuman (1980). Unlike this, when the conflict is more focused on a particular matter, such as in the case of disputes prompted by economic and social policy measures, expected durations will be shorter. Besides the role of protocol complexity in the length of the bargaining process, the variable cause of dispute will help to unravel the role of other aspects, such as labour-related disputes (regarding wages, industrial restructuring policies, employment adjustments, organization and working conditions, and firings and breach of contracts), trade union issues, sympathetic disputes, and other non-labour disputes, on strike duration. As for this variable, there are disparities between risks (Table 5). The pooled and non agreement cases are the more similar. For them, duration significantly decreases with most of the dispute causes in relation to the reference category (disputes arising from collective bargaining), being the cause "sympathetic disputes" the one associated to shorter duration. However, for the agreement risk, labour-related disputes, economic policy, and other non-labour related causes, significantly increase duration. Furthermore, all the motives but collective bargaining increase the probability of the strike ending in non agreement (Table 4). To sum up results in relation to the agreement outcome, collective bargaining not only increases the probability of agreement but also reduces the length of a strike ending with agreement. The protocol story works for non-agreement but it does not work for agreement, probably because of relative inefficiencies in dealing with the protocol complexities in bargaining units unable to reach an agreement against bargaining units reaching it. We could also explain this opposite effect of collective bargaining if it is the case that more complex protocols are correlated with strikes ending without agreement and more simple ones to strikes ending in agreement. However, we do not have available information to find out whether or not this is the case.

\section{Party initiating the action}

This variable provides information about who is originally the main strike caller. The legal organization of a strike may rely on a group of workers; the workers' committee; trade unions; or other parties. On the 
one hand, we expect shorter durations when the main strike call comes from relevant unions, since they usually have better information about the conflict, its origins, and the way to solve it, and stronger bargaining power. On the other hand, however, the backing of a labour organization may affect strike costs (decreasing them) by providing organizational assistance to the strikers, or by raising community support for the walkout, and then contribute to longer durations. Thus, on theoretical grounds, the effect for this variable is uncertain. Our results present disparities among risks (Table 5). Strikes started by a group of workers are the omitted category. For the pooled case, duration decreases when the strike is called for workers' committees and CCOO and increases when the other trade unions initiate the dispute (different to CCOO and UGT). For the non agreement case, duration also decreases when the strike is organized by workers' committees and CCOO. For the agreement case, duration increases with strikes organized by other trade unions (different to CCOO and UGT). In relation to the probability of a strike ending with non agreement, this probability increases when the party initiating the action are workers' committees and other trade unions (different to UGT but including CCOO, although the latter is included when we accept up to a $10 \%$ significance level). ${ }^{12}$

\section{Type of applicable collective agreement}

In the registry, it is specified whether the applicable agreement is of workplace, firm, group of firms, sector, or whether there are several applicable agreements or even a lack of existence of collective agreement. For this variable we find that both for the pooled and non agreement case the presence of several applicable agreements lowers duration (Table 5). The applicable agreement being of workplace is the omitted category. Furthermore, for the pooled case, duration rises with a lack of collective agreement. For the agreement risk, no significant differences according to this variable arise. The probability of ending the strike with non agreement increases with the existence of several applicable collective agreements (Table 4). Given that several applicable agreements significantly shortens non-agreement strikes and increases this ending probability, this could confirm that being quite covered by previous contracts may have an influence decreasing the bargaining resistance of unions and workers, given that they probably have a better outside option (in the sense of pre-strike conditions at the end of the strike failure).

\footnotetext{
12 As noticed by Card and Olson (1995), it can happen that some unions self select into strikes with a high probability of success.
} 


\section{Type of institutional sector}

This variable captures the type of firm (private or public firms, public administration and others -mixture of private and public firms or several institutional sectors-) in which the strike takes place. We expect longer duration of strikes in private firms than in the public sector due to the special labour legislation in the public sector, especially in the public administration. Moreover, the public sector usually provides services of wide demand and hence the impact on the public opinion of strikes in this sector is greater and exerts more pressure to shorten the duration of the conflict. In addition, we expect a weaker role of the strike as an information revealing device of the size of the pie to split between parties for the public sector than for private firms, reinforcing shorter strikes. As regards this variable, private firms are found to face longer strikes than the other sectors in the pooled and non agreement cases (Table 5). Regarding the agreement case, duration diminishes if the strike takes place in the public administration. Then, there are in general longer durations for strikes in private firms than in the public sector. However, the probability of ending the strike without agreement increases in all the institutional sectors as compared with private firms (Table 4).

\section{Policy variables}

We have included two policy variables controlling for the effects of the two major labour reforms in Spain during the analysed period. Policies that lower the expected negotiation costs and/or the uncertainty in the process help to improve bargaining efficiency and then contribute to shorten strikes. The first policy variable is the Legal reform 1992, which turned into the Law of Urgent Measures about Employment Promotion and Unemployment Protection. This labour reform was put in practice without the agreement of the economic and social parties affected and in an environment of breaking-off relations between government and unions. In April 1992 unions called for a general strike in order to protest against that Law. The government main objectives with this Law were to make more difficult the eligibility for unemployment benefits and to discourage temporal hiring. This reform did not bring the government the expected results, mainly because of the workers' reluctance and its failure in lowering the high rates of temporary contracts. The second policy variable is the labour reform of 1997. In 1997, the Inter-federal Agreement for Employment Stability was signed, with the consensus of the two major unions, CCOO and UGT, and employers' confederations, CEOE and 
CEPYME (organisation similar to CEOE but for small and medium sized firms). A noteworthy feature is that this labour reform was agreed and implemented with the consensus of social parties. The main objective of the agreement was to reduce the widespread use of fixed-term contracting. The effects of this reform were very positive both in terms of permanent job creation (80 percent of net job creation was permanent) and in terms of reduction in the rate of temporary contracts (mainly in the private sector). According to our results (Table 5), the labour reform of 1992 does not seem to have affected strike duration. The labour reform of 1997 is non significant for the pooled case too, but has opposite and significant effects for agreement (diminishing duration) and non agreement (increasing duration). This reform led to a sizeable and significant increase in the risk of ending with agreement and to a fall in the risk of ending without agreement (Table 4).

\section{Business cycle}

Kenan (1985), Tracy (1986, 1987), Vroman (1989), Harrison and Stewart (1989, 1994), Booth and Cressy (1990), and Ingram et al. (1993), among others, have shown the relevance of including some variables to control for economic cycle variations in the analysis of strike duration. These variables proxy for the changing costs in which both unions and firms incur. Several of the previous studies have found that strike duration is countercyclical (booms are associated with shorter durations). When product demand is high, the firm's strike costs are also high. The firm may be willing to settle more quickly. Booms can also be associated with an increase in the speed of negotiations. One of the usual variables in this literature to capture the cycle has been the Unemployment rate. However, as mentioned in Cramton et al. (1999), we can explain a conflicting view of the effect of tightness in the labour market on the length of strikes. Labour market tightness (low unemployment) is expected to decrease strike duration if it increases both production inefficiencies and firm operating costs during a strike (by making replacement of workers more difficult and more expensive). However, in tight labour markets the income of striking workers during a strike may be higher (by making part-time job opportunities more plentiful), thus inducing longer durations. Furthermore, when tight labour markets increase the union's bargaining power and lead to greater wage demands and a slower path of decline of them over the course of a strike, the rise in duration could be reinforced. To sum up, the effect of the unemployment rate on strike duration is ambiguous on theoretical grounds. Thus, we 
include an additional variable to account for the effect of the business cycle: Real GDP growth rate.

From our results, the unemployment rate seems to bear no relationship with both strike duration and with the probabilities of different outcomes (Tables 5 and 4, respectively). This can be explained by the highly segmented nature of the Spanish labour market, in which a significant segment has enjoyed relatively high job security because of legal and financial impediments to dismissal that have made them immune to the moderating pressures traditionally associated with high unemployment. The traditional low flexibility of the labour market has mitigated the impact of high unemployment on strike duration. In addition, unemployment has been relatively concentrated in the low-skill, young, new entrants to the labour market, or older and redundant workers. With respect to the Real GDP growth rate (Table 5), we find it non-significant for the pooled case. However, it is significantly pro-cyclical in the agreement case and counter-cyclical in the non agreement case. This variable increases the chances of ending the strike without agreement (Table 4).

\section{Unions' information for negotiations}

We try to capture, to some extent, the possible unions' lack of satisfaction from previously signed contracts (derived from incomplete information about firms' product market, demand conditions and firms' profitability) through the inclusion of the one-year lagged value of the inflation rate (Inflation rate ( $t-1)$ ) to proxy the unions' expectations for future negotiations. ${ }^{13}$ As McConnell (1989) pointed out, as contracts are rarely fully indexed, unexpected inflation over the previous contract may affect wage negotiations. Probably this effect is to some extent mitigated in Spain due to the presence of indexation clauses in collective bargaining contracts. $^{14}$ To capture this "price catch-up" effect, the previous year inflation rate is included in the model. A higher level of inflation in the previous year would make unions ask for higher initial nominal wages demands and then would contribute to explaining, other things being constant, longer strike durations. We find a non significant effect of the one-year lagged value of the inflation rate for the pooled case and opposite effects for the other cases (Table 5). Previously unexpected and

${ }^{13}$ We are implicitly assuming that the higher the inflation rate on the previous year the higher the probability of part of that inflation being unanticipated and then uncompensated in previous contracts. As a consequence there would have been quasirents captured by firms in previous contracts.

${ }^{14}$ Notice, however, the absence of these clauses for civil servants. 
uncompensated inflation diminishes duration in the case of strikes ending with agreement and increases duration for strikes ending without agreement. The first might be explained by the fact that firms with high rents, aware of the previous uncompensated inflation, reach shortly an agreement with the union and workers. The second might be due to firms with low rents, which leads to longer duration by itself, and without reaching an agreement because even being conscious they cannot compensate previous inflation. Finally, higher previous inflation reduces the probability of the strike ending without agreement (Table 4).

\section{Conclusion}

This paper has analysed empirically whether there are differences in the factors driving strikes to end through different ending routes. To this end, we have applied semi-parametric duration methods and estimated a competing risks hazards model to the population of Spanish strikes over 1986-1999. The regression analysis has been carried out using a Cox competing risks proportional hazards model (Cox, 1972).

We find that Spain shows some peculiar features, such as the high percentage of strikes ending in non agreement, which may be related to the distinctive features of the bargaining process, in which most workers are already covered by a collective bargaining agreement and considering the strike as a device to achieve better conditions.

From the estimation results we find that the number of workers involved generally increases all the risks of ending a strike, that is, it contributes to shorten durations. The reason is that this variable increases the costs in which the firm and workers have to incur during the strike. The existence of minimum services has the effect of minimising the impact of strikes both for customers and employers. Thus, we find that it contributes to explain longer strikes durations. Also, the degree of strike support increases strike durations. Besides, the presence of several applicable agreements lowers duration. Furthermore, strikes in private firms tend to last longer than strikes in the public sector, which might be related both to the special legislation in the public sector and to the pressure exerted by the public opinion when public services are distorted. We find that under social and political consensus, the 1997 reform increases the risk of ending the strike with agreement. Regarding the two proxies for the economic cycle, we have shown the inability of the unemployment rate to explain strikes duration in Spain. With respect to the real GDP growth rate, the evidence suggests that strike duration is pro-cyclical for strikes ending with agreement and counter-cyclical for 
strikes ending without agreement. Finally, previously unexpected and uncompensated inflation diminishes duration in the case of strikes ending with agreement and increases duration for strikes ending without agreement. The first result could be explained by the fact that firms with high rents, aware of the previous uncompensated inflation, are more willing to reach an agreement with the union and workers. The second result might be explained by the fact that firms with low rents do not reach an agreement because, even being aware of uncompensated inflation, cannot afford to compensate workers for it.

From a policy standpoint, although rather tentative, our results suggest that bargaining at the workplace is desirable since the probability of agreement is higher. It seems that a lower degree of centralisation in negotiations might help alleviate labour disputes. Furthermore, labour reforms under social consensus make both the agreement outcome more likely and faster to reach.

Summing up, this study shows the relevance of distinguishing between different strikes endings. Besides the general pattern applicable to most of the strikes, we have been able to detect special features in the comparison of results between strikes ending with and without agreement.

\section{References}

Ashenfelter, O. and Johnson, G.E. (1969), "Bargaining Theory, Trade Unions and Industrial Strike Activity", American Economic Review, 59, 1, pp. 35-49.

Booth, A. and R. Cressy (1990), "Strikes with Asymmetric Information: Theory and Evidence", Oxford Bulletin of Economics and Statistics, 52, pp. 269-295.

Breslow, N.E. (1974), "Covariance Analysis of Censored Survival Data", Biometrics, 30, pp. 89-99.

Card, D. (1990a), "Strikes and Bargaining: A Survey of the Recent Empirical Literature", American Economic Review, 80, 2, pp. 410-415.

Card, D. (1990b), "Strikes and Wages: A Test of an Asymmetric Information Model", Quarterly Journal of Economics, 105, pp. 625-655. 
Card, D. and Craig A. Olson, (1995), "Bargaining Power, Strike Durations and Wage Outcomes: An Analysis of Strikes in the 1880,s", Journal of Labour Economics, 13, 1, pp. 32-61.

Cox, D.R., (1972), "Regression Models and Life Tables", Journal of the Royal Statistical Society, 34, pp. 187-220.

Cox, D.R. (1975), "Partial Likelihood”, Biometrica, 60, pp. 269-276.

Cramton, P., M. Gunderson and J. Tracy (1999a), "Impacts of Strike Replacement Bans in Canada", Labor Law Journal, 50.

Cramton, P., M. Gunderson and J. Tracy (1999b), "The Effect of Collective Bargaining Legislation on Strikes and Wages", Review of Economics and Statistics, 81, pp. 475-487.

Cramtom, P. and Tracy, J. (2003), "Unions, Bargaining and Strikes", chap 4, pp. 86-117, in International Handbook of Trade Unions, Edited by Addison, J.T and Schnabel, C. Edward Elgar Publishing. UK.

Harrison, A. and M. Stewart (1989), "Cyclical Fluctuations in Strike Durations", American Economic Review, 79, pp. 827-841.

Harrison, A. and M. Stewart (1994), "Is Strike Behaviour Cyclical?" Journal of Labor Economics, 124, pp. 524-553.

Hayes, B. (1984),"Unions and Strikes with Asymmetric Information", Journal of Labour Economics, 2, 1, pp. 57-83.

Hicks, J.R. (1932), The Theory of Wages, London: Macmillan Press.

Ingram, P.N., D. Metcalf and J. Wadsworth (1993), "Strike Incidence and Duration in British Manufacturing Industry in the 1980's", Industrial and Labor Relations Review, 46, pp. 704-717.

Jiménez-Martin, S. (1999), "Controlling for Endogeneity of Strike Variables in the Estimation of Wage Settlement Equations", Journal of Labour Economics, 17, 3, pp. 583-606.

Jiménez-Martín, S. and Marco, M. L. (1998), "El Conflicto en las Relaciones Laborales: Un Panorama”. Revista de Economía Aplicada, 17, pp. 81-107. 
Jiménez-Martín, S., Labeaga, J. M. and Marco, M. L. (1996), "Algunos Factores Explicativos de la Existencia de Huelgas durante la Negociación Colectiva”, Investigaciones Económicas, XX (2), pp. 217-242.

Kennan, J. (1980), "Pareto Optimality and the Economics of Strike Duration", Journal of Labor Research, 1, pp. 77-94.

Kennan, J. (1985), "The Duration of Contract Strikes in U.S. Manufacturing", Journal of Econometrics, 5, pp. 5-28.

Kennan, J. and Wilson, R. (1989), "Strategic Bargaining Models and Interpretation of Strike Data", Journal of Applied Econometrics, 4, pp. 87130.

Kennan, J. and Wilson, R (1990), "Can Strategic Bargaining Models Explain Collective Bargaining Data?", American Economic Review, 80, 2, pp. 405-409.

Kennan, J. and Wilson, R (1993),"Bargaining with Persistent Private Information", Journal of Economic Literature, 31, 1, pp. 45-104.

Kolbfleisch, J.D. and Prentice, R. L. (1980), The Statistical Analysis of Failure Time Data. John Wily \& Sons.

Marco, M. L. (1996), La Conflictividad Laboral en España. Un Análisis Empírico de la Actividad Huelguística en el Periodo 1986-1994. Tesis Doctoral. Universidad de Valencia.

McConnell, S. (1989), "Strike, Wages, and Private Information", American Economic Review, 79, pp. 801-815.

Narendranathan, W and Stewart, M.B. (1991), "Modelling the Probability of Leaving Unemployment: Competing Risks Models with Flexible Baseline Hazards", Journal of the Royal Statistical Society, Applied Statistics, 42, pp. 63-83.

Reder, M.W. and Neumann, G.R. (1980), "Conflict and Contract: The Case of Strikes”, Journal of Political Economy, 88, pp. 867-886.

Ross, A. M. (1948), Trade Union Wage Policy, California Press, Berkeley. 
Tracy, J. (1986), "An Investigation into the Determinants of U.S. Strike Activity", American Economic Review, 76, pp. 423-436.

Tracy, J. (1987), "An Empirical Test of an Asymmetric Information Model”, Journal of Labour Economics, 5, pp. 149-173.

Vroman, S. (1989), "A Longitudinal Analysis of Strike Activity in U.S. Manufacturing: 1957-1984”, American Economic Review, 79, pp. 816-826. 